\title{
URINARY INDOLES AND OTHER “EHRLICH'S REAGENT REACTORS" IN RHEUMATOID ARTHRITIS
}

\author{
BY \\ MARTTI OKA \\ Department of Medicine, Central Hospital, Kuopio \\ AND \\ V. V. E. LEPPÄNEN \\ Central Laboratory, Kivelä Hospital, Helsinki, Finland
}

Recent investigations suggest that certain tryptophan metabolites such as serotonin or 5-hydroxytryptamine (5-HT) or derangements in tryptophan metabolism may be related to diseases of the connective tissue. Three of four patients with malignant carcinoid reported by Sjoerdsma, Weissbach, and Udenfriend (1956) also had rheumatoid arthritis. An association of functioning carcinoid syndrome with scleroderma has also been observed (Zarafonetis, Lorber, and Hanson, 1958).

One possible link between diseases of the connective tissue and 5-HT is the action of the latter on fibroblasts as in malignant carcinoid, where fibroblastic proliferation of the subendocardium and valves of the right side of the heart are sometimes found (Mattingly and Sjoerdsma, 1956; McKusick, 1956; Bean and Funk, 1957; Thorson, 1958). In the case reported by Bean and Funk, intense fibrosis also developed in post-operative abdominal adhesions. It appears that 5-HT may stimulate fibroblasts to form collagen. It has been suggested by Zarafonetis (1959) that the fibrotic changes in scleroderma and other related conditions result from a deranged interaction of 5-HT-mono-amine oxidase mechanisms at the tissue level.

The 5-HT content of thrombocytes has been found to be slightly lower in patients with rheumatoid arthritis than in control patients (Kerby and Taylor, 1959). Rheumatoid arthritics also show an exaggerated reactivity to 5-HT, which can be neutralized by 5-HT antagonists (Scherbel and Harrison, 1959). Preliminary observations on the uptake of radioactive 5-HT in rheumatoid arthritics suggest that the uptake increases when active disease is present, and decreases as the arthritis improves. If a potent 5-HT antagonist (1-methyl-methergine tartrate) is injected into an inflamed joint, the pain is reduced significantly, in most instances within a few minutes. Joint swelling and inflammation subside temporarily but usually not completely (Scherbel, 1959).

Clinical and experimental evidence that defective tryptophan metabolism may be concerned in scleroderma was presented by Price, Brown, Rukavina, Mendelson, and Johnson (1957), who demonstrated a large urinary output of tryptophan intermediate metabolites (especially kynurenine, 3hydroxykynurenine, and kynurenic acid) in three cases of scleroderma after the ingestion of $2 \mathrm{~g}$. tryptophan. Pyridoxine and/or $\mathrm{Na}_{2}$ EDTA administration brought the metabolism back to normal.

The present investigation is concerned with urinary indoles and other "Ehrlich's reagent reactors" in rheumatoid arthritis.

\section{Material and Methods}

25 cases of rheumatoid arthritis were studied which met the criteria of the American Rheumatism Association (Ropes, Bennett, Cobb, Jacox, and Jessar, 1957), and 34 healthy persons from the hospital staff acted as controls.

Urinary indoles were studied by using two paper chromatographic methods:

(1) According to Jepson (1955).- - The urine sample is applied to the paper without preliminary purification.

(2) According to Hanson and Serin (1955).- The urine sample undergoes purification before it is applied to the paper.

The chromatography is carried out first in alkali and secondly in acid. Ehrlich's reagent was used for the detection of spots. The sensitivity of the reaction is $0.3 \mu \mathrm{g}$. 5-hydroxyindole acetic acid (5-HIAA) or $1 \mu \mathrm{g}$. indolyl acetic acid (IAA). The following standards were used: urea, tryptophan, 5-hydroxytryptamine, 5-hydroxyindole acetic acid, indolyl acetic acid, indolyl butylic acid, tryptamine, indole, skatole, kynurenic acid, anthranilic acid, 3-hydroxyanthranilic acid, kynurenine, xanthurenic acid, nicotinic acid. 


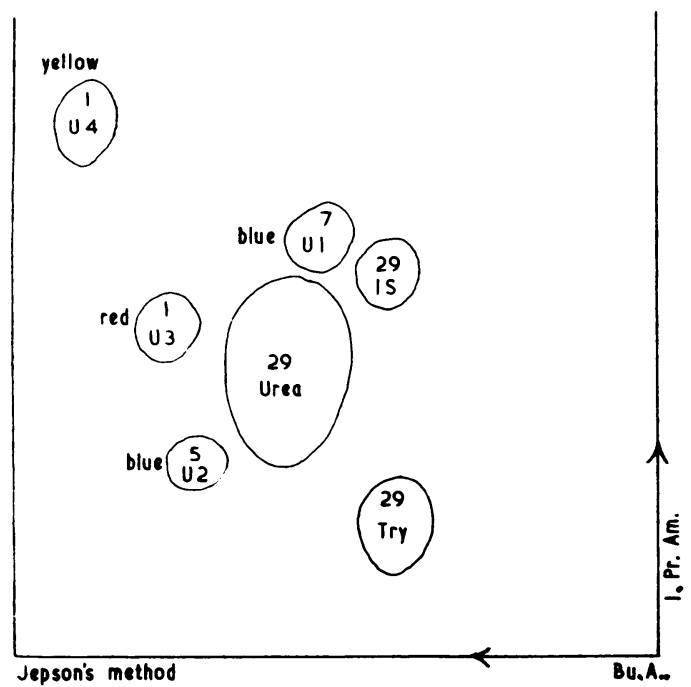

Fig. 1.-Chart of normal spots in 29 chromatograms made by Jepson's method.

Bu. A. = Butanol-acetic acid ( $n$-butanol $120 \mathrm{ml}$. + water $50 \mathrm{ml}$. + glacial acetic acid $30 \mathrm{ml}$.).

I. Pr. Am. = Isopropanol-ammonia (isopropanol $200 \mathrm{ml}$. + water $20 \mathrm{ml}$. $\rightarrow$ ammonia $10 \mathrm{ml}$. (sp. gr. 0-880)).

The numerals in each ring indicate the number of cases in which each type of spot was observed.

U 1 Probably N-methylhydroxytryptamine

U 2 Probably same as Jepson's spot U 2

U 3 Probably acetyltryptophan

U 4 Probably anthranilic acid derivative

Quantitative determinations of 5-hydroxyindoles in morning urine were made by the method of Hanson and Serin.

Paper chromatographic studies of morning urine without supplementary L-tryptophan were carried out in twenty rheumatoid arthritics and 31 healthy controls. Urinary indole output before and after the ingestion of a loading dose of L-tryptophan was measured in five rheumatoid arthritics and three controls; 2 g. L-tryptophan was administered orally in a single dose at 8 a.m., and 24-hr urine collections were started one day before the L-tryptophan ingestion and were continued for three days.

\section{Results}

\section{(1) Studies without Supplementary L-Tryptophan Controls}

(i) Jepson's Method-Chromatography was performed in 29 cases. The number of spots varied from three to six (average 3.8). In addition to urea, tryptophan (Try) and indoxylsulphate (IS) were demonstrated in all cases. Indolyl acetic acid (IAA) was found in two cases. Four different unidentified spots were detected. A chart of the spots normally occurring in Jepson's system is presented in Fig. 1.

(ii) Hanson and Serin's Method.-Chromato-

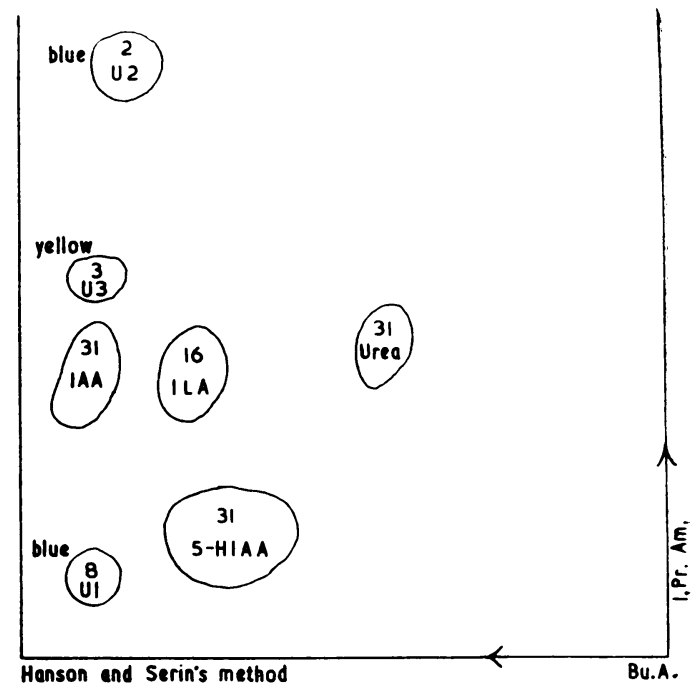

Fig. 2.-Chart of normal spots in 31 chromatograms made by Hanson and Serin's method. The numerals in each ring indicate the number of cases in which each type of spot was observed.

$\mathbf{U} \mathbf{I}$ and $\mathbf{U} \mathbf{2}=$ Unidentified

U $3=$ Probably an anthranilic acid derivative

graphy was performed in 31 cases. The number of $\overrightarrow{0}$ spots was three to seven (average $4 \cdot 1$ ). More thay of five spots were found in only one case. Urea, IAAand 5-HIAA were demonstrated in all cases. Indoly lactic acid (ILA) was found in sixteen cases. Three different unidentified spots were detected (Fig. 2).

The paper chromatographic results were considered abnormal in rheumatoid arthritis cases only if spots other than those presented in Figs 1 and 2 could be detected.

\section{Rheumatoid ARTHRitics}

(i) Jepson's Method.-The spots varied in the twenty cases studied from three to seven (average 4.5). In only one case were there more than six spots.

One abnormal spot occurred in six cases, two in three cases, and three in one case. All these abnormal spots were yellow. The most characteristic localizations on the paper were "middle left" (seven cases), "up left" (four cases), and "below urea" (four cases). Yellow spots were detected in twelve cases out of twenty, but in the control series they were seen in only one case out of 29.

(ii) Hanson and Serin's Method.-The number of spots varied from two to six (average 4). It $\stackrel{0}{\overparen{D}}$ remained within normal limits in all cases.

One abnormal spot occurred in four cases and two in one case. Yellow spots were detected in 
eight cases, whereas they were seen in only three out of 31 control cases. They were located either "up left" or "middle left" on the paper. Unidentified red spots were detected in two instances.
5-HIAA appeared in fourteen paper chromatograms (70 per cent.).

Some of the indole chromatograms of rheumatoid arthritics are presented in Fig. 3.
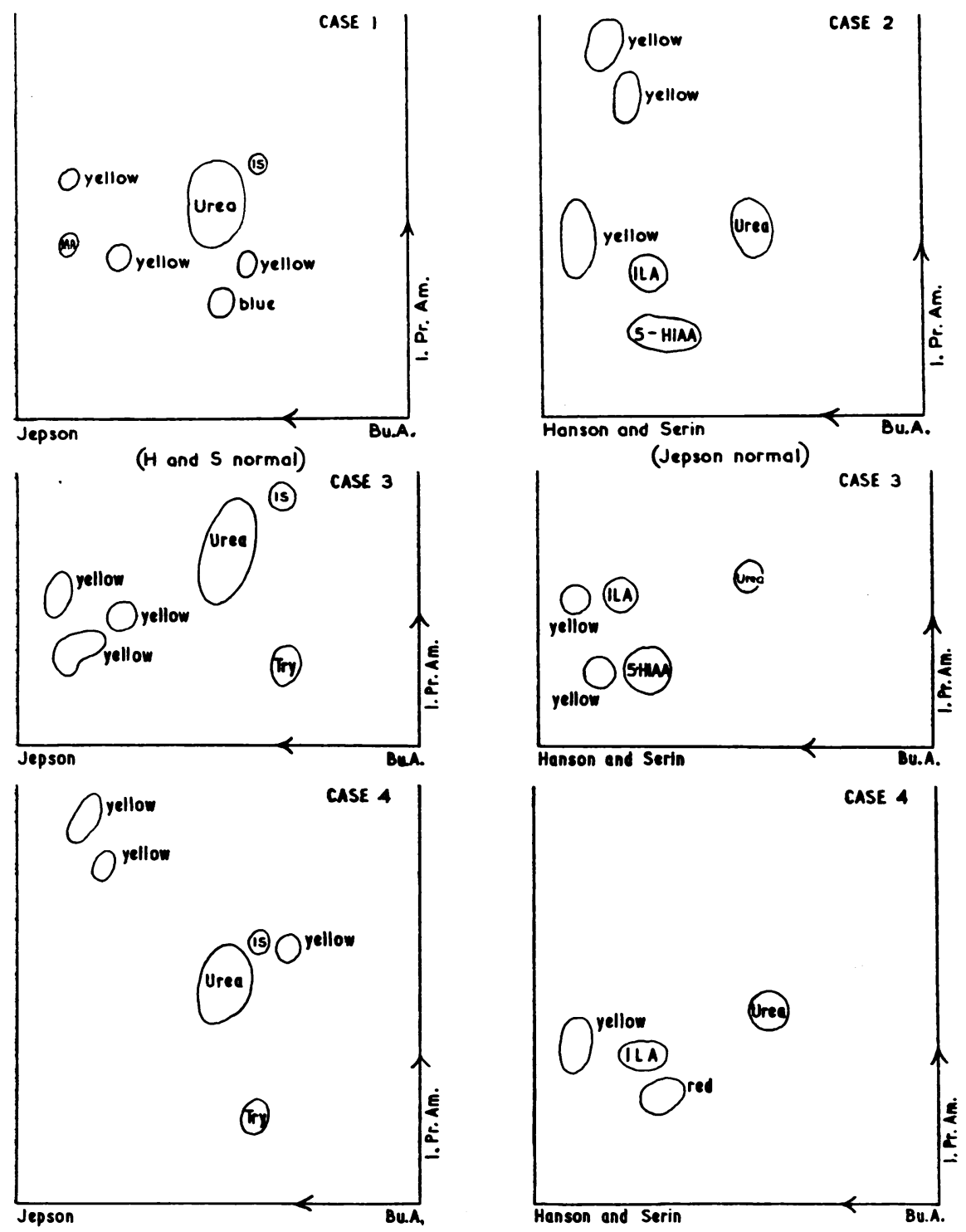

Fig. 3.-Six typical charts from cases of rheumatoid arthritis. 
URINARY CONCENTRATION OF 5-HYDROXYINDOLES

Controls.-The excretion of 5-hydroxyindoles varied from 0.22 to $1.46 \mathrm{mg}$. per $100 \mathrm{ml}$. morning urine (average $0.67 \mathrm{mg} . / 100 \mathrm{ml}$.).

Rheumatoid Arthritics.-The excretion varied from 0.23 to $0.78 \mathrm{mg} . / 100 \mathrm{ml}$. (average 0.41 $\mathrm{mg} . / 100 \mathrm{ml}$.).

\section{(2) Studies with Supplementary L-Tryptophan}

The effect of the loading dose of L-tryptophan on the indole chromatograms in three controls and five rheumatoid arthritics was nil or very slight. No significant alterations in the chromatographic pattern occurred during the loading with the amino acid.

\section{Discussion}

An attempt has been made in this investigation to elucidate the intermediate metabolism of tryptophan in rheumatoid arthritis by studying the excretory pattern of urinary indoles and other "Ehrlich's reagent reactors". Taken as a whole, the indole chromatograms in the rheumatoid group deviated clearly from the control group. Unusual spots were detected in twelve cases out of twenty. In seven cases one abnormal spot occurred, which shows that the differences in individual chromatograms were generally slight.

Almost all the abnormal spots were yellow. In many of them the colour and localization resembled those of 3-hydroxyanthranilic acid and anthranilic acid, which were among the standards used. The assumption that the changes in indole chromatograms in rheumatoid arthritis were based mainly on a derangement of tryptophan metabolism via the kynurenine pathway seems reasonable. Tests with L-tryptophan loading did not reveal any further qualitative abnormalities.

The paper chromatographic pattern of urinary indoles in rheumatoid arthritis was not specific, since similar patterns have been observed by the authors in other systemic diseases (Oka and Leppänen, 1960).

Work is now in progress to determine the quantitative urinary excretion of certain kynurenine metabolites in rheumatoid arthritis.

\section{Summary}

The presence in the urine of indoles and other "Ehrlich's reagent reactors" was studied in twenty cases of rheumatoid arthritis and 31 healthy controls by two paper chromatographic methods and by quantitative determination. Paper chromatography before and after the ingestion of a loading dose of L-tryptophan was performed in five rheumatoid arthritics and three controls.

Slight abnormalities were observed in seven cases? of rheumatoid arthritis, and more pronounced $\overline{0}$ abnormalities in five other cases. The papers chromatograms showed no specific pattern. L- $\frac{\mathbb{Q}}{2}$ tryptophan loading had no effect on the indoles chromatograms in the cases studied.

5-hydroxyindole acetic acid could be detected in the chromatograms of 70 per cent. of the rheumatoid $\vec{\omega}$ arthritics and all of the control cases.

The concentration of 5-hydroxyindoles in the morning urine was slightly lower in rheumatoid $\dot{\infty}_{\infty}^{\circ}$ arthritics than in the control cases.

\section{REFERENCES}

Bean, W. B., and Funk, D. (1957). Trans. Amer. clin. climatol. Ass.for $1956,68,111$

Hanson, A., and Serin, F. (1955). Lancet, 2, 1359.

Jepson, J. B. (1955). Ibid., 2, 1009.

Kerby, G. P., and Taylor, S. M. (1959). J. clin. Invest., 38, 1059.

Mattingly, T. W., and Sjoerdsma, A. (1956). Mod. Conc. cardiovasc. Dis., 25, 337.

McKusick, V. A. (1956). Bull. Johns Hopk. Hosp., 98, 13

Oka, M., and Leppänen, V. V. E. (1960). Acta med. scand. (in the

press). J. M., Brown, R. R., Rukavina, J. G., Mendelson, C., \&్\&dG Johnson, S. A. M. (1957). J. invest. Derm., 29, 289.

Ropes, M. W., Bennett, G. A., Cobb, S., Jacox, R., and Jessar, R. (1957). Ann. rheum. Dis., 16, 118.

Scherbel, A. L. (1959). Arthr. and Rheum., 2, 372.

and Harrison, J. W. (1959). Ibid., 2, 370.

Sjoerdsma, A. Weissbach, H., and Udenfriend, S. (1956). Amer. J. Med., 20, 520.

Thorson, A. H. (1958). Acta med. scand., 161, Suppl. No. 334.

Zarafonetis, C. J. D. (1959). Ann. intern. Med., 50, 343.

Lorber, S. H., and Hanson, S. M. (1958). Amer. J. med. Sci.,으 236, 1 .

Indoles et d'autres substances sensibles au réactif d'Ehrlich dans l'urine des cas d'arthrite rhumatismale

\section{RÉSUMÉ}

On rechercha dans l'urine de 20 cas d'arthrite rhumatismale et de 31 témoins sains des indoles et d'autres substances sensibles au réactif d'Ehrlich, au moyen de deux응 méthodes chromatographiques sur papier et par des dosages quantitatifs. La chromatographie sur papiero avant et après l'ingestion d'une dose massive de 1-tryptophane fut effectuée chez 5 rhumatisants arthritiques et $D$ 3 témoins.

On observa de légères anomalies dans 7 cas d'arthrite rhumatismale et des anomalies plus prononcées dans 5 autres cas. Les chromatogrammes sur papier ne révélèrent pas d'image spécifique. L'ingestion de仓 1-tryptophane n'eut pas d'effet sur les chromatogrammes des indoles dans les cas étudiés.

L'acide 5-hydroxyindole acétique fut décélé dans les chromatogrammes de $70 \%$ des rhumatisants et de tous les témoins.

Le taux des 5-hydroxyindoles dans l'urine matinale? fut un peu plus bas chez les rhumatisants arthritiques que chez les témoins. 
Indoles $\left(\mathrm{C}_{8} \mathrm{H}_{7} \mathrm{~N}\right)$ y otras substancias sensibles al reactivo de Ehrlich en la orina de casos de artritis reumatoide

\section{Sumario}

Se estudiaron en la orina de 20 casos de artritis reumatoide y de 31 testigos sanos los índoles y otras substancias sensibles al reactivo de Ehrlich, por medio de dos métodos cromatográficos sobre papel y por determinación cuantitativa. La cromatografía sobre papel antes y después de la ingestión de una dosis de carga de 1 -triptófano fué efectuada en 5 casos de artritis reumatoide $y$ en 3 testigos.
Se observaron ligeras anomalías en 7 casos de artritis reumatoide y anomalías más pronunciadas en 5 otros casos. Los cromatogramas sobre papel no revelaron imagen específica alguna. En los casos estudiados la ingestión de 1-triptófano fué inefectivo sobre los cromatogramas de los indoles.

El ácido 5-hidroxi-índol acético fué encontrado en los cromatogramas del $70 \%$ de los artríticos y de todos los testigos.

La cifra de 5-hidroxi-índoles en la orina matinal fué un poquito más baja en los artríticos reumatoides que en los testigos. 